\title{
PERLINDUNGAN HUKUM BAGI KONSUMEN TERHADAP PRA KEPEMILIKAN RUMAH SANGAT SEDERHANA DI KOTA PAYAKUMBUH*
}

\author{
FAISAL \\ STIH Putri Maharaja Payakumbuh, \\ Jln. Kalimantan Rt/Rw. 05/01 Kel. Padang Tangah Balai Nan Duo Kec. Payakumbuh Barat \\ Kota Payakumbuh \\ e-mail: faisal.buchari61@gmail.com
}

\begin{abstract}
Home is one of the basic human needs for shelter. For that the construction of houses and settlements continue to be increased at affordable prices, especially by the low-income community. Consumers have paid a down payment and have made the addition of home building, but after more than 9 (nine) years running signing the credit agreement agreement with the bank that will provide mortgage facilities has not been realized. So the opportunity for consumers to have a home to be delayed can even be closed at all. This research was an analytical descriptive that describes the overall symptoms and legal aspects of consumer protection in the pre sale house purchase agreement is very simple. The data obtained in the analysis and interpreted logically and systematically by using a qualitative juridical approach. The results of field research indicated that there is no consumer protection in the pre-sale agreement to buy a very simple house on Bumi Ngalau Indah housing consumers. Where the consumers who have paid the advance position in the eyes of the same law with consumers who have made a perfect sale and purchase agreement. Based on the results of this study it is advisable that receipts as receipts for advance payment in the prerecord of sale and purchase of houses are very simple to mention about what rights and obligations between consumers and developers, or the addition of other clauses so that consumers are not always on the weak side.
\end{abstract}

Keywords: Legal Protection, Consumer and House Very Simple

\begin{abstract}
Abstrak
Rumah merupakan salah satu kebutuhan dasar manusia untuk tempat tinggal. Untuk itu pembangunan rumah dan pemukiman terus ditingkatkan dengan harga terjangkau, terutama oleh golongan masyarakat yang berpenghasilan rendah. Konsumen telah membayar uang muka yang dan telah melakukan penambahan bangunan rumah, namun setelah lebih kurang 9 (sembilan) tahun berjalan penandatanganan perjanjian akad kredit dengan bank yang akan memberi fasilitas KPR belum juga terealisasi. Sehingga kesempatan konsumen untuk memiliki rumah menjadi tertunda bahkan bisa tertutup sama sekali. Penelitian ini bersifat deskriptif analitis yaitu memaparkan keseluruhan gejala dan aspek-aspek hukum tentang perlindungan konsumen dalam pra perjanjian jual beli rumah sangat sederhana. Data yang didapat di analisis dan di tafsirkan secara logis dan sistimatis dengan mempergunakan pendekatan secara kualitatif yuridis. Hasil penelitian dilapangan menunjukkan bahwa belum ada perlindungan konsumen dalam pelaksanaan pra perjanjian jual beli rumah sangat sederhana pada konsumen perumahan Bumi Ngalau Indah. Dimana konsumen yang telah membayar uang muka posisinya di mata hukum sama dengan konsumen yang telah melakukan perjanjian jual beli secara sempurna. Berdasarkan hasil penelitian ini disarankan agar kwitansi sebagai tanda terima uang muka dalam pra perjanjian jual beli rumah sangat sederhana dicantumkan tentang apa yang menjadi hak dan kewajiban antara konsumen dan pengembang, atau penambahan klausula lainnya agar konsumen tidak selalu berada pada pihak yang lemah.
\end{abstract}

Kata kunci: Perlindungan Hukum, Konsumen dan Rumah Sangat Sederhana

\footnotetext{
* Naskah diterima: 24 Februari 2018, direvisi: 1 Maret 2018, disetujui untuk terbit: 24 Maret 2018
} 
Faisal: Perlindungan Hukum Bagi Konsumen Terhadap Pra Kepemilikan Rumah Sangat...

\section{PENDAHULUAN}

Perumahan dalam kehidupan seharihari merupakan salah satu kebutuhan dasar manusia di samping sandang dan pangan, karena perumahan mempunyai fungsi dan peranan yang sangat penting di dalam kehidupan manusia, baik untuk tempat tinggal, tempat usaha, perkantoran, dan sebagainya. Rumah bagi masyarakat Indonesia juga merupakan cerminan dari diri pribadi baik perseorangan maupun di dalam suatu kesatuan dan kebersamaan dengan lingkungannya.

Namun demikian, belum semua anggota masyarakat dapat menikmati atau memiliki rumah yang layak, sehat, aman, dan serasi. $^{1}$ Oleh karena itu, upaya pembangunan perumahan dan pemukiman terus ditingkatkan untuk menyediakan jumlah perumahan yang makin banyak dan dengan harga yang terjangkau, terutama oleh golongan masyarakat yang berpenghasilan rendah.

Seiring dengan semakin tingginya tingkat pertumbuhan jumlah kebutuhan terhadap perumahan. Perumahan yang dibutuhkan masyarakat itu tentu rumah yang layak huni dan memenuhi syarat kesehatan.

Pembangunan perumahan dan pemukiman yang layak huni dan memenuhi syarat kesehatan tersebut diarahkan untuk meningkatkan kualitas kehidupan keluarga dan masyarakat serta menciptakan suasana kerukunan hidup

1 Andi Hamzah, I Wayan Suadra, dan M.Manulu, 1990, Dasar-Dasar Hukum Perumahan. Rineka Cipta, Jakarta, Hlm. 3 keluarga dan kesetiakawanan sosial masyarakat dalam rangka membentuk lingkungan persemaian. Nilai agama dan budaya bangsa serta pembinaan watak anggota keluarga.

Pembangunan perumahan dan pemukiman, baik pembangunan perumahan baru maupun pemugaran di pedesaan dan perkotaan, bertujuan untuk memenuhi kebutuhan masyarakat akan tempat tinggal baik dalam jumlah maupun kualitas dalam lingkungan yang sehat dan layak huni serta memenuhi kebutuhan akan suasana kehidupan yang memberi rasa aman, damai, tenteram, dan sejahtera. $^{2}$

Berangkat dari kondisi tersebut, pemerintah maupun swasta melakukan pembangunan perumahan. Guna memenuhi kebutuhan masyarakat akan tempat tinggal yang disesuaikan dengan kemampuan masyarakat sebagai konsumen, dengan harga terjangkau, terutama oleh masyarakat golongan menengah ke bawah.

Untuk mengakomodasi kepentingan golongan ini, keluarlah keputusan Menteri Negara Perumahan Rakyat No. 01/KPTS/1994 tentang Perubahan surat Keputusan No. 005/KTPS/1993 tentang pengadaan Perumahan dan Pemukiman dengan dukungan Fasilitas Kredit Pemilikan Kapling Siap Bangun (KPKSB), Kredit Pemilikan Rumah Sangat Sederhana (KP-RSS), Kredit Pemilikan Rumah Sederhana (KP-RS), dan, Kredit

2 Lihat TAP MPR No. II/MPR 1998 Mengenai GBHN Huruf F. 
Pemilikan Rumah Susun Sederhana (KPRusun).

Sebelum dan sesudah krisis moneter juli 1997, keinginan masyarakat untuk memiliki rumah yang siap digunakan atau ditempati meningkat. Meskipun rumah belum jadi, bahkan belum dibangun atau masih dalam tahap perencanaan, konsumen sudah ada yang menghubungi pengembang. Ini merupakan hasil dari pemasaran rumah yang begitu gencar dari pengembang.

Terhadap pelaksanaan pembangunan perumahan tersebut, ada kalanya muncul permasalahan seperti penjualan rumah fiktif, penjualan rumah di atas tanah bermasalah, baik antara pengembang dengan pemilik tanah maupun antara pengembang dengan Bank sebagai kreditor, mutu bangunan di bawah standar, panjar telah dibayar akad kredit tidak jadi, banjir dan lain sebagainya. Halhal di atas sangat merugikan pihak konsumen.

Undang-Undang Nomor 8 Tahun 1999 Tentang Perlindungan Konsumen mengatur mengenai hak dan kewajiban dari konsumen dan pelaku usaha, tanggungjawab pelaku usaha, pembinaan dan pengawasan pemerintah, penyelesaian sengketa dan sanksi. Namun dalam pelaksanaannya kita lihat masih jauh dari harapan.

Proses pelaksanaan jual beli rumah sangat sederhana ada beberapa tahap transaksi yang dilalui oleh konsumen. Pertama yaitu tahap pra-transaksi konsumen masih mencari atau menerima informasi/keterangan dimana rumah dapat diperoleh, berapa harga dan syarat-syarat yang harus dipenuhi, serta mempertimbangkan berbagai fasilitas atau kondisi dari transaksi yang di inginkan. Salah satu informasi itu adalah melalui iklan yang diedarkan oleh para pengembang, melalui pertemuan khusus antara pengembang dengan calon konsumen yang difasilitasi oleh pemda setempat atau salah satu instansi tertentu. Dimana di dalam iklannya atau brosurbrosur serta sosialisasi dari pengembang sering menjanjikan bahwa perumahan yang strategis, bebas banjir dan berbagai fasilitas lainnya.

Informasi dari iklan yang benar dan bertanggung jawab akan memberikan dampak positif pada putusan pilihan konsumen. Sedangkan iklan yang sebaliknya melebih-lebihkan. Menyesatkan setengah benar atau menipu, akan potensial menimbulkan kerugian pada konsumen. Berangkat dari iklan dan keyakinan yang diberikan oleh tim marketing pengembang ini konsumen membeli rumah.

Walaupun materi iklan perumahan sepenuhnya dapat dipertanggungjawabkan. Contohnya di dalam iklan daerahnya bebas banjir, ternyata memang tidak daerah rawan banjir. Namun pada saat telah ada perjanjian kesepakatan antara penjual/pengembang dengan konsumen, dengan cara pembayaran uang muka atau pelunasan berjangka malah sering meninggalkan masalah atau kenyataan pahit bagi konsumen. 
Faisal: Perlindungan Hukum Bagi Konsumen Terhadap Pra Kepemilikan Rumah Sangat...

Salah satu penyebabnya adalah permasalahan tanah, dimana Bank yang memberikan kredit konstruksi kepada pengembang tidak sama dengan Bank yang memberikan kredit kepemilikan rumah kepada calon konsumen. Sehingga pada saat perjanjian kredit antara konsumen dengan Bank sebagai kreditor yang memberikan fasilitas kredit perumahan tidak terlaksana, dimana pada saat yang sama pengembang harus melakukan kewajiban pembayaran kredit kepada Bank yang telah memberikan kredit konstruksinya.

Karena pengembang telah melakukan wanprestasi, maka Bank pemberi kredit konstruksi menyita tanah beserta rumah tersebut untuk dilelang pada pihak ketiga. Sebagaimana terjadi pada perumahan yang dibangun oleh PT. Samala Corda Mandiri di kelurahan Balai Panjang Kecamatan Payakumbuh Barat Kota Payakumbuh pada tahun $1996 .^{3}$

Konsumen yang telah melakukan kesepakatan perjanjian jual beli dengan pengembang yang ditandai dengan pembayaran uang muka oleh konsumen kepada pengembang, bahkan ada konsumen yang telah melakukan perbaikan terhadap rumah yang akan diambilnya, namun rumah yang telah siap untuk di akad kreditkan dengan Bank pemberi fasilitas kredit tersebut tidak pernah terealisasi. Sehingga konsumen menurut penulis, dirugikan dan posisinya sangat lemah untuk mendapatkan perlindungan hukum.

3 Berita Acara Gugatan PT. Samala Corda Mandiri pada Bank BRI Cabang Payakumbuh.
Lemahnya posisi konsumen untuk mendapatkan perlindungan hukum disebabkan perangkat hukum yang melindungi konsumen belum bisa memberi rasa aman di samping pengawasan yang kurang ketat dari Pemerintah Daerah setempat. Dan juga belum diaturnya undang-undang tersendiri mengenai perjanjian baku yang dapat melindungi konsumen perumahan secara lebih baik, dan kurangnya pemahaman masyarakat terhadap hukum umumnya, khususnya menyangkut perlindungan konsumen. Apalagi terhadap konsumen yang baru melakukan kesepakatan perjanjian jual beli yang ditandai dengan pembayaran uang muka, terdapat anggapan bahwa mereka belum berhak mendapatkan perlindungan berdasarkan Undang-Undang Nomor 8 Tahun 1999 Tentang Perlindungan Konsumen karena di anggap belum masuk fase kontrak jual beli.

Menurut Yusuf Shofie, di dalam perjanjian standar/baku itu sering dimuat klausula-klausula pengecualian (exception clause), misalnya meniadakan tanggungjawab pengembang dalam hal terlambat menyerahkan bangunan, membebaskan pengembang dari klaim atas kondisi/kualitas bangunan yang melampaui batas waktu 100 hari sejak serah terima bangunan fisik dan sebagainya. ${ }^{4}$ sehingga timbul bagaimana dengan tanggung jawab pengembang terhadap kerugian konsumen yang telah membayar uang muka, yang rata-rata

4 Yusuf Soufie, 2003, Perlindungan Konsumen dan Instrumen-Instrumen Hukumnya. PT. Citra Aditya Bakti, Bandung, Hlm. 75 
telah sembilan tahun yang lalu membayar uang muka sampai saat sekarang belum juga akad kredit sebagaimana dialami oleh konsumen perumahan Bumi Ngalau Indah yang dibangun oleh PT. Samala Corda Mandiri.

salah satu fungsi konsumen adalah sebagai sumber pemupukan modal dan keuntungan bagi pengembang. Begitu strategis dan pentingnya posisi konsumen dalam bisnis perumahan sehingga sangat wajar bila konsumen perlu mendapatkan perlindungan dan jaminan akan terpenuhi hak-hak yang seharusnya didapatkannya.

Berdasarkan hal-hal yang telah dikemukakan di atas, penulis tertarik meneliti tentang "Perlindungan Hukum Bagi Konsumen Terhadap Pra Kepemilikan Rumah Sangat Sederhana Di Kota Payakumbuh".

Dari hal tersebut di atas tentunya menimbulkan pertanyaan bagaimana bentuk perlindungan hukum bagi konsumen yang telah membayar uang muka dalam pelaksanaan proses awal dalam perjanjian jual beli rumah sangat sederhana.

\section{METODE PENELITIAN}

Penulis menggunakan metode penelitian Hukum Deskriptif Analitis. Data penelitian yang dianalisis diharapkan dapat menggambarkan keseluruhan gejala dan aspek hukum secara rinci dan akurat tentang perlindungan hukum bagi konsumen dalam pra jual beli rumah sangat sederhana.

\section{HASIL DAN PEMBAHASAN}

\section{De Jure}

Pembelian rumah yang dilakukan konsumen dengan cara memesan rumah yang akan dibeli dengan surat bukti pemesanan rumah yang telah disediakan pihak pengembang, dengan surat bukti pemesanan oleh konsumen berarti konsumen setuju membeli rumah dengan jumlah uang muka tertentu dan harga kelebihan luas tanah dari standar. Pembayaran uang muka dan harga kelebihan luas tanah dari standar ini bisa dilakukan secara tunai dan juga bisa diangsur dengan batas waktu yang disetujui antara konsumen dengan pengembang.

Pembayaran uang muka dan harga kelebihan luas tanah yang dilakukan oleh konsumen berarti telah ada perjanjian pendahuluan atau pra perjanjian jual beli rumah. Hal ini dapat kita katakan bahwa dengan pembayaran uang muka telah dapat memenuhi beberapa asas dari hukum kontrak antara lain:

1. Asas kebebasan berkontrak; asas kebebasan berkontrak ini yang dianalisis dari pasal 1338 ayat (1) KUH Perdata, yang berbunyi "semua perjanjian yang dibuat secara sah berlaku sebagai undang-undang bagi mereka yang membuatnya". Yang mana asas ini memberikan kebebasan kepada para pihak untuk membuat atau tidak membuat perjanjian, mengadakan perjanjian dengan siapapun, menentukan isi perjanjian, pelaksanaan, dan pernyataannya, dan 
Faisal: Perlindungan Hukum Bagi Konsumen Terhadap Pra Kepemilikan Rumah Sangat...

menentukan bentuknya perjanjian, yaitu tertulis atau lisan.

2. Asas konsesualisme; asas konsesualisme dapat disimpulkan dalam pasal 1320 ayat (1) KUH Perdata. Dimana salah satu syarat sah nya perjanjian yaitu adanya kesepakatan kedua belah pihak. Artinya bahwa perjanjian pada umumnya tidak dibuat secara formal, tetapi cukup dengan adanya kesepakatan kedua belah pihak. Kesepakatan merupakan persesuaian kehendak dan pernyataan yang dibuat oleh kedua belah pihak.

3. Asas Pacta Sunt Servanda; juga disimpulkan dalam pasal 1338 ayat (1) KUH Perdata yang berbunyi "perjanjian yang dibuat secara sah berlaku sebagai undang-undang" yang mana asas ini disebut juga dengan asas kepastian hukum yang berhubungan dengan akibat perjanjian.

Demikian juga terhadap sebuah MoU, dimana walaupun MoU tidak dikenal dalam sistem hukum konvensional Indonesia, namun KUH Perdata yang merupakan dasar hukum dari setiap perjanjian tidak pernah mengecualikan berlakunya hukum perjanjian terhadap suatu MoU, sehingga Munir Fuadi mengatakan bahwa MoU secara yuridis formal juga berlaku ketentuan KUH Perdata sebagai mana juga terhadap perjanjian-perjanjian lainnya. Untuk itu MoU sama saja kekuatan hukumnya dengan perjanjian lain.
Di samping itu unsur-unsur pokok perjanjian jual beli adalah barang dan harga. Sesuai dengan asas konsensualisme yang menjiwai hukum perjanjian KUH Perdata, perjanjian jual beli itu sudah lahir pada detik tercapainya kata sepakat mengenai barang dan harga. Begitu kedua belah pihak setuju tentang barang dan harga, maka lahirlah perjanjian jual beli.

Barang yang menjadi objek perjanjian jual beli harus cukup tertentu, setidak-tidaknya dapat ditentukan wujud dan jumlahnya, pada saat ia akan diserahkan hak miliknya kepada si pembeli. Dengan demikian adalah sah menurut hukum jual beli yang objeknya rumah yang akan dibangun oleh pengembang. Jual beli rumah sangat sederhana ini ada yang dilakukan atau terjadi setelah rumah selesai dibangun dan ada yang belum siap atau sedang dalam pembangunan. Jadi jual beli rumah-rumah sangat sederhana ditinjau dari unsur-unsur essentialia perjanjian jual beli telah sah menurut hukum.

Menurut pasal 1320 KUH Perdata syarat sah suatu perjanjian adalah: kesepakatan, kecakapan para pihak, suatu hal tertentu, dan sebab yang halal. Jika ditinjau dari perjanjian jual beli rumah sangat sederhana maka syarat ini dipenuhi. Hal ini dapat dilihat dari kesepakatan para pihak yaitu pengembang dan konsumen telah sepakat untuk mengadakan suatu perjanjian jual beli dimana konsumen yang berminat untuk membeli rumah melakukan pemesanan rumah kepada pengembang dan dilanjutkan dengan membayar uang muka 
rumah tersebut. Dalam pembayaran uang muka ini pengembang memberikan kwitansi pembayaran kepada konsumen. Berarti di sini saat adanya kata sepakat di antara para pihak tanpa dituntutnya suatu bentuk cara (formalitas) apapun seperti tertulis, pemberian tanda panjar. Kecakapan para pihak; dalam hal ini para pihak adalah pengembang merupakan suatu perusahaan yang berbentuk badan hukum dalam wilayah Republik Indonesia yang bergerak di bidang perumahan dan pemukiman dan yang berhak membuat perjanjian itu adalah direktur perusahaan pengembang dan juga oleh kepala bagian pemasaran atas nama direktur. Konsumen yang mengambil perumahan Bumi Ngalau Indah semuanya berusia 30 tahun ke atas pada saat pembayaran uang muka dilakukan, berarti sudah dewasa dan tidak di bawah pengampuan, suatu hal tertentu; yaitu jual beli tanah dan bangunan di atasnya, sebab yang halal; yaitu yang tidak bertentangan dengan kesusilaan, ketentuan, dan undang-undang. Jadi syarat sah suatu perjanjian telah dipenuhi, sehingga perjanjian jual beli rumah sederhana dan rumah sangat sederhana ini adalah sah menurut hukum.

Dengan uraian di atas konsumen yang telah membayar uang muka posisinya dimata hukum sama dengan konsumen yang telah melakukan perjanjian jual beli rumah secara paripurna. Untuk itu ia berhak mendapatkan perlindungan konsumen sebagaimana layaknya konsumen yang telah melakukan perjanjian jual beli secara sempurna.

\section{De Facto}

Konsumen perumahan Bumi Ngalau Indah yang terletak di kelurahan Bali Panjang Nagari Limbukan Kecamatan Payakumbuh Barat dibangun oleh developer PT. Samala Corda Mandiri dengan luas area 2,5 ha dan telah ditumbuhkan rumah sebanyak 40 unit. Dari jumlah unit rumah yang tumbuh, 20 rumah diantaranya telah ada konsumen atau calon pembelinya.

Pembangunan perumahan Bumi Ngalau Indah ini telah dimulai tahun 1997 dimana pada saat itu pemasarannya telah dijalankan, sehingga dalam proses pembangunan rumah berjalan, proses administrasi calon konsumen juga disiapkan secara berbarengan dengan harapan rumah siap dibangun dan konsumen sudah wawancara maka proses akad kredit dapat dilangsungkan. Sehingga investasi pengembang cepat kembali sehingga dapat dijadikan modal untuk menumbuhkan perumahan tahap berikutnya.

Konsumen Perumahan Bumi Ngalau Indah ini telah membayar uang muka kepada pengembang sebagai tanda telah adanya suatu kesepakatan antara konsumen dengan pengembang yang ditandai dengan sehelai kwitansi tanda terima dari pengembang. Konsumen yang telah membayar uang muka ini sekarang menempati rumah yang diambilnya tersebut bahkan ada diantara konsumen telah melakukan pengembangan sesuai kemampuan dan kebutuhan masingmasing konsumen. 
Faisal: Perlindungan Hukum Bagi Konsumen Terhadap Pra Kepemilikan Rumah Sangat...

Sampai saat sekarang konsumen Perumahan Bumi Ngalau Indah yang telah membayar uang muka ini belum juga terealisasi akad kreditnya dengan bank yang akan memberikan fasilitas kredit pemilikan rumah. Walaupun sudah hampir sembilan tahun semenjak dimulainya pembangunan dan pembayaran uang muka.

Dengan lalainya pengembang memproses tercapai realisasi akad kredit antara konsumen dengan bank telah menjadikan nasib konsumen terkatungkatung. Dimana konsumen hanya dapat menempati rumah yang diambilnya namun belum dapat memilikinya. Hal ini akan membawa kerugian kepada konsumen sebab jangka waktu kredit akan tergantung kepada usia konsumen dengan standar masa pensiun bagi pegawai negeri. Semakin bertambah usia konsumen semakin pendek jangka waktu kredit, sedangkan semakin pendek jangka waktu kredit semakin besar jumlah cicilan dan semakin besar jumlah cicilan semakin besar premi asuransi kebakaran serta premi asuransi kredit, dan ini akan sangat memberatkan bagi konsumen.

Bahkan bisa saja bank tidak meloloskan permohonan kredit konsumen yang berkonsekwensi kepada kerugian kepada konsumen. Pada hal konsumen tidak hanya sebatas membayar uang muka dan harga kelebihan tanah tetapi juga telah melakukan pengembangan terhadap rumah yang diambilnya

Hasil penelitian di lapangan sampai saat sekarang belum ada perlindungan kepada konsumen. Di samping pengembang belum melihat itikad baiknya untuk melanjutkan proses akad kredit dan konsumen juga tidak melakukan upaya hukum apapun untuk memperjuangkan nasibnya yang terkatung-katung tersebut.

\section{SIMPULAN}

Berdasarkan pembahasan terhadap hasil penelitian tentang perlindungan konsumen dalam pra perjanjian jual beli rumah sangat sederhana pada konsumen perumahan Bumi Ngalau Indah Kelurahan Balai Panjang Kota Payakumbuh, penulis dapat mengambil kesimpulan bahwa:

Dalam prakteknya tidak ada perlindungan konsumen dalam pelaksanaan pra perjanjian jual beli rumah sangat sederhana yang ditandai dengan pembayaran uang muka yang merupakan pra kepemilikan rumah, dimana setingkat MoU saja kekuatan hukumnya sama dengan perjanjian lainnya begitu juga dengan sebuah konsensus telah melahirkan suatu perjanjian maka terhadap konsumen yang telah membayar uang muka posisinya di mata hukum sama dengan konsumen yang melakukan perjanjian jual beli secara sempurna, untuk itu konsumen berhak mendapatkan perlindungan sebagaimana halnya dengan konsumen yang telah melakukan perjanjian jual beli dengan sempurna.

Di dalam mengemukakan saran-saran ini, agar terwujudnya perlindungan konsumen yang baik dalam pra perjanjian jual beli rumah sangat sederhana ini, maka penulis menyarankan agar: 
1. Dalam kwitansi sebagai tanda pembayaran atas panjar atau uang muka dalam pengikatan perjanjian jual beli rumah perlu ditambahkan klausul-klausul lainnya untuk memperkuat posisi konsumen. Sehingga apabila terjadi kelalaian oleh pengembang sebelum akad kredit terjadi yang menyebabkan ruginya konsumen, dimana pada saat itu konsumen tidak selalu berada pada pihak yang lemah

2. Undang-undang Nomor 8 tahun 1999 tentang Perlindungan Konsumen adalah segala upaya yang menjamin adanya kepastian hukum untuk memberi perlindungan kepada konsumen disarankan perlu adanya suatu parameter atau indikator yang jelas dan tegas dalam penyelesaian sengketa antara konsumen dan pengembang. Serta perlunya sosialisasi agar konsumen mengerti tentang hak dan kewajibannya. Kepada pengembang diberikan kewajiban untuk mensosialisasikan Undang-undang Perlindungan Konsumen tersebut.

\section{UCAPAN TERIMA KASIH}

Puji dan Syukur penulis ucapkan ke hadirat Allah SWT yang telah memberikan Rahmat dan Karunia-Nya, sehingga akhirnya penulis dapat menyelesaikan penulisan karya ilmiah ini yang berjudul: "Perlindungan Hukum Bagi Konsumen Terhadap Pra Kepemilikan Rumah Sangat Sederhana Di Kota Payakumbuh".

Penulis menyadari bahwa tanpa bantuan dan dorongan dari berbagai pihak tidak mungkin karya ilmiah ini dapat diselesaikan. Oleh karena itu pada kesempatan ini dengan segala kerendahan hati, penulis ingin mengucapkan terima kasih dan penghargaan yang sebesarbesarnya kepada:

1. Bapak Dr. Eviandi Ibrahim S.H., M.Hum selaku Ketua Sekolah Tinggi Ilmu Hukum Putri Maharaja Payakumbuh

2. Seluruh rekan-rekan Dosen Sekolah Tinggi Ilmu Hukum Putri Maharaja yang tidak dapat penulis sebutkan satu-persatu. 
Faisal: Perlindungan Hukum Bagi Konsumen Terhadap Pra Kepemilikan Rumah Sangat...

\section{DAFTAR PUSTAKA}

Andi Hamzah, I Wayan Suadra, dan M. Manalu, 1990, Dasaar-Dasar Hukum Perumahan, Rineka Cipta, Jakarta.

Berita Acara Gugatan PT. Samala Corda Mandiri pada Bank BRI Cabang Payakumbuh
TAP MPR No II/MPR 1998 Mengenai GBHN Huruf $F$

Yusuf Suofie, 2003Perlindungan Konsumen dan InstrumenInstrumen Hukumnya, Cutra Aditya Bakti, Bandung. 